\title{
The consumer market is the most important factor in the region's sustainable development during the pandemic
}

\author{
Natalya Novikova ${ }^{1 *}$, Larisa Dianova ${ }^{1}$ and Rafaela Znachek $^{2}$ \\ ${ }^{1}$ Ural State University of Economics, 8 Marta Str., 62, 620144 Ekaterinburg, Russia \\ ${ }^{2}$ Odessa National Academy of Food Technologies, Kanatna str. 112, Odessa, 65039 Ukraine
}

\begin{abstract}
During the coronavirus pandemic the problems of sustainability of the Russian economy, as well as the economy of regions that form it, sharply worsened. The protracted, global course of the COVID-19 epidemic has given the exceptional urgency to the problem of the sustainable development of regions. There is a lack of knowledge of the global, national, regional dynamics in the conditions of the epidemic, despite the world scale of the problem. The sustainability and integrity of the country depend on the sustainability of the regional social and economic system. The purpose of this research is to identify trends in the development of the regional consumer market in the conditions of the pandemic, to reveal its significance in forming the region's sustainable development. To conduct the research the authors used the first statistic data about the functioning of the national and regional consumer market in the conditions of the pandemic. The object of the study is one of the Russian regions - the Sverdlovsk region. The theoretical basis of the research is the concept of the sustainable development of the social and economic system.
\end{abstract}

\section{Introduction}

The lack of the experience and practice in fighting against the pandemic of the century COVID-19 puts many governments in a difficult situation when taking necessary measures to fight against the disease. The humanistic mission to save people's lives at the cost of limiting the livelihoods of the population is the only acceptable variant for a favorable outcome of the fight against the disease. At the same time, the economic costs of such a decision constrain the economy, disrupt the production and supply chains. This fact can subsequently be the cause of the economic depression, economic crisis on the regional dimension, the national and global economy in general.

\footnotetext{
*Corresponding author: novikova@usue.ru
} 
The speed of emergence of new viruses that infect people is rapidly increasing. A continuous virus monitoring system is needed to prevent a global catastrophe. The respect for the principles of social justice will make it more possible to ensure the flow of resources, which are necessary for fighting against the infection, and to weaken the vulnerability to the existing risks. It is necessary to ensure the existence and development of businesses at the national and regional levels, to prevent the growth of unemployment, to ensure the food supplies, to provide benefits and jobs for employees of non-working and idle enterprises and to reduce vulnerability to the existing risks.

\section{Materials and Methods}

Regional economics studies the patterns of spatial organization of the production [1]. Federal purposes and objectives are implemented at the sub-regional (actually regional) and local territorial levels. At the regional level the result of spatial policy should be the forming the local environment which is favorable for the population's livelihoods and maintaining the effective economic activity. Regional economic development is vulnerable to economic downturns, threats and upheavals caused by external and internal factors.

The concept of the sustainable development is coming to the forefront of the modern researches including regional ones.

Sustainable development in translation (eng. - sustainable development, fr.développement durable) means the harmonious, long-term, balanced development, expansion and growth.

There are different approaches to defining the concept of sustainable development. Some authors associate sustainable development with the concepts of security, reliability [2], the others define it as constancy and strength [3] or as the constant development process [4]. The most optimal variant to define sustainable development, in our opinion, is the ability of the system to work steadily, to function, develop and go from one sustainable state to another under the influence of external and internal factors.

During the pandemic, which has led to the uncertainty, instability and destabilization, the management of social and economic systems has become more difficult. In such conditions the sustainable development of the region as the social and economic system cause the increased interest of scientists and government specialists.

The issues of solving the problems of the social and economic system sustainability are reflected in the works of scientists $[4,5,6]$. The parameters of the social and economic system include its dynamism and at the same time integrity, immutability of its properties. The sustainable development of the social and economic system is characterized by qualitative changes in the system without transformation of its features, such as the ability to resist destructive external and internal factors, to maintain the equilibrium state and the ability of the system to the self-regulation and self-development. The loss of the sustainability of the system threatens to destroy it. This fact allows to draw a parallel between the sustainability and survival.

The conclusions of the International Commission [7] on the environment and development identified the main principles of the sustainable development, including: the improvement of the quality of life, the guaranteed human health, the rational structure of consumption and production, the fight against poverty, as well as the issues related to the environmental management and ecology. In such a complex of provisions, the social and economic system is an environmental system, aggregating environmental, economic and social aspects into one. Since the late 80 -s of XX century the theory and practice of the 
sustainable development is the focus of attention of scientists, specialists and politicians both in Russia and abroad.

According to researchers from different countries [6, 2, 8, 4], these are regions that should be the spaces for implementing the theory of the sustainable development. Regions are comparable in size, they are historically sustainable entities with a certain set of national and ethical characteristics. They have experience in combining market transformation incentives with government regulation policies. Focusing on the regional economic system, rather than on the industry one, is a priority purpose for the development of the Russian Federation [9].

We understand the sustainability of the regional social and economic system as its ability to develop steadily and function in the long term in the conditions of destabilizing factors of the internal and external environment. In this way it achieves positive dynamics in the level and quality of the population life. It is based on the sustainable and balanced reproduction of social, resource and economic potentials.

The balanced and sustainable development of regions is largely determined by their ability to respond to any challenges and threats that arise under the influence of various external and internal factors. Therefore, to ensure a balanced social and economic development of regions, «it is important to identify the degree and the character of the regional sustainability in the conditions of global development uncertainty; to develop recommendations for adequate measures in the field of spatial development of the country, while maintaining the viability of regions in crisis situations» [10, p. 47].

Measuring the degree of the regional sustainability is an important factor in insuring the economic growth and improving the well-being of the population without deterioration of different parameters of the regional economic system. In 2019 the Russian Federation government approved «The strategy of the spatial development of the Russian Federation». It is aimed at ensuring the sustainable and balanced spatial country's development, reducing interregional differences in the level and quality of the population's life, accelerating economic growth and technological development, as well as ensuring national security [9].

\section{Results and Discussion}

In the current situation we see increasing importance of the researches of the status and development of the consumer market. These studies allow to identify not only its main trends and problems, but also public satisfaction with offers of products and services taking into account strategic development benchmark of the country in general and ensuring sustainable economy of its regions.

We understand the consumer market as the system of economic relations that arise between sellers and customers in the process of purchasing them. This system is inherent to a certain territory (city, urban area, city with surroundings, rural settlement, municipal formation) [11].

The consumer market of the Sverdlovsk region is limited by administrative borders, where commodity-money relations are carried out. The consumer market includes the market of foodstuff, the market of non-foodstuff, the market of consumer services, which are interconnected. They meet the needs of the population and should contribute to the sustainable development of the region. The consumer market regulates economic relations between individual subjects of the reproduction process. It also participates in the circulation of funds and ensures the continuity of the reproduction process.

During the pandemic, the state restricts economic activity in order to reduce mortality. With the introduction of the restrictive measures, the supply from producers falls, the 
demand from consumers decreases, the income of the population also decreases, and accordingly, this affects the producers of goods. The service sector, small and mediumsized businesses suffer. They don't have the «airbag» and may be on the verge of bankruptcy. During this period, it is important to ensure the sustainability of the consumer market, to ensure the regional reproduction process and to monitor the formation and regulation of prices based on supply and demand. It is important to take measures in the event of the production and consumption imbalances, to stimulate the development of the consumer market economy through the use of digital technologies and to ensure the development of advanced, high-tech enterprises in the consumer market.

It is necessary to rely on the perspective industries in the country's regions to achieve the purpose of sustainable development of the Russian Federation regions. In accordance with Annex 1 of the strategy of the spatial development of the Russian Federation for the period up to 2025 [9] the Sverdlovsk region can strengthen its competitive advantage in such industries as mining and motor vehicles production. In addition to the mining and machine-building industries of the Sverdlovsk region, it is necessary to develop such sectors of the consumer market as the production of beverages and foodstuff, transportation and storage, tourism, hotels and catering enterprises, crop production and livestock.

A few months after the beginning of the epidemic, we can make some cautious generalizing estimates based on operational statistics and the analysis of the taken measures.

In the period of the pandemic some factors begin to influence on the sustainable development of the region and steady functioning of the consumer market with the new force. These factors are: the level of the population's incomes, the amount of monetary savings of the population, the employment, the population's economic activity, the current level of unemployment, the natural and mechanical movement of the population in the territory.

The data in the table 1 illustrate more sustainable character of the regional consumer market in the Sverdlovsk region compared to the national one - declining in the retail trade turnover in the Sverdlovsk region in April and May was less than in Russia in general.

So, the consumer market of the Sverdlovsk region has shown great sustainability to the crisis situation. We consider that this is related with the following factors.

1. Special location of the region.

The Sverdlovsk region occupies the "middle" economic and geographical position between the European and Asian parts of the country. It is the perspective area for the building and developing the logistics centers. A large number of new high-tech distribution centers are being built in the Sverdlovsk region. Many retail chains like "Auchan", "Verniy", "Magnit",

Table 1. Comparison of the retail trade turnover in the Sverdlovsk region, the Russian Federation for January-July in 2019-2020

\begin{tabular}{|l|l|l|l|l|}
\hline \multirow{3}{*}{ Month } & \multicolumn{2}{|l|}{$\begin{array}{l}\text { Retail trade turnover in the Sverdlovsk region } \\
\text { (the current prices) }\end{array}$} & \multicolumn{2}{l|}{$\begin{array}{l}\text { Retail trade turnover in } \\
\text { the Russian Federation } \\
\text { (the current prices) }\end{array}$} \\
\cline { 2 - 5 } & mln. rubles. & in $\%$ to the & mln. rubles. $\%$ in to the
\end{tabular}




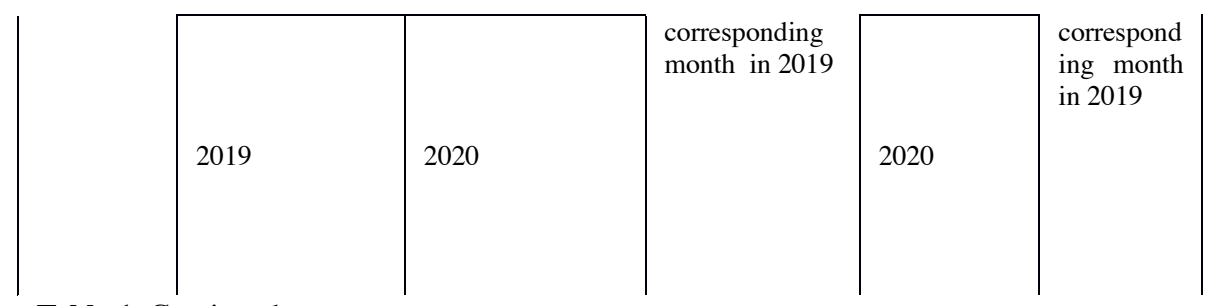

Table 1. Continued

\begin{tabular}{|l|l|l|l|l|l|}
\hline January & 90864,40 & 93631,80 & 101,2 & 2639,8 & 102,7 \\
\hline February & 87320,50 & 91452,20 & 103,4 & 2628,9 & 104,7 \\
\hline March & 98223,40 & 103180,00 & 103,1 & 2917,5 & 105,7 \\
\hline April & 95280,90 & 82835,60 & 84,2 & 2110 & 76,8 \\
\hline May & 97285,50 & 83901,90 & 83,7 & 2257,3 & 80,8 \\
\hline June & 98087,20 & 88256,80 & 87,4 & 2623,5 & 92,3 \\
\hline July & 100401,40 & 94128,70 & 90,9 & no data & no data \\
\hline
\end{tabular}

Note: Compiled by authors according to materials: Office of the Federal State Statistics Service in the Sverdlovsk and Kurgan regions, https://rosstat.gov.ru/

"Lenta", "X5 Retail Group" have their own distribution centers, which made it possible to increase stocks in April and May in 2020 and provide the population with the goods in the larger volume than in the Russian Federation in general.

2. Developed transport system in the region.

The transport system of the Sverdlovsk region is well-established, because it has not only regional significance, but it also provides its services to neighboring territories, as well as meets international needs. Well-established transport logistics made it possible to provide the population with the goods in a short time.

3. The high degree of the penetration of the retail chain structures.

The Sverdlovsk region has a high degree of the penetration of the retail chain structures into its territory (more than $30 \%$ of the total turnover of the retail trade), which operate in the consumer market and also related areas (logistics, storage, production of goods, etc). Retail chains carried out measures centrally and dynamically to provide the population with the essential goods.

4. The high level of the trade space availability of the population.

The availability of the trade space of the population has played its role. By 01.01.2018 the actual number of local retail trade properties was 10652 entities. It exceeded the minimum standard by 535 properties. The stores managed to «react» to the decreasing inventory during the period of high consumer demand, and retail facilities caught

Table 2. Comparison of the retail trade turnover of foodstuffs and non-foodstuffs in the Sverdlovsk region, the Russian Federation for January-July in 2019-2020

\begin{tabular}{|c|c|c|c|c|c|c|c|c|c|}
\hline \multirow[b]{2}{*}{$\begin{array}{c}\text { M } \\
\mathbf{o} \\
\mathbf{n} \\
\mathbf{t} \\
\mathbf{h}\end{array}$} & \multicolumn{5}{|c|}{ The Sverdlovsk Region } & \multicolumn{4}{|c|}{ The Russian Federation } \\
\hline & $\begin{array}{l}\text { Retail } \\
\text { trade } \\
\text { turnove } \\
r \text { of } \\
\text { foodstu } \\
\text { ffs in } \\
2020, \\
\text { mln, } \\
\text { rubles, }\end{array}$ & $\begin{array}{l}\text { Retail } \\
\text { trade } \\
\text { turnover } \\
\text { of non- } \\
\text { foodstuffs } \\
\text { in } 2020 \text {, } \\
\text { mln, } \\
\text { rubles, the } \\
\text { current }\end{array}$ & $\begin{array}{c}\text { Retail } \\
\text { trade } \\
\text { turnov } \\
\text { er of } \\
\text { foodst } \\
\text { uffs } \\
\text { (comp } \\
\text { arable } \\
\text { prices) }\end{array}$ & $\begin{array}{l}\text { Retail } \\
\text { trade } \\
\text { turnov } \\
\text { er of } \\
\text { non- } \\
\text { foodst } \\
\text { uffs } \\
\text { (comp } \\
\text { arable }\end{array}$ & $\begin{array}{l}\text { Share of } \\
\text { non- } \\
\text { foodstuf } \\
\text { fs } \\
\text { /foodstu } \\
\text { ffs retail } \\
\text { trade } \\
\text { turnover } \\
\text { in the }\end{array}$ & $\begin{array}{l}\text { Retail } \\
\text { trade } \\
\text { turnov } \\
\text { er of } \\
\text { foodst } \\
\text { uffs in } \\
2020 \text {, } \\
\text { mln, } \\
\text { rubles, }\end{array}$ & $\begin{array}{c}\text { Retail } \\
\text { trade } \\
\text { turnov } \\
\text { er of } \\
\text { foodst } \\
\text { uffs } \\
\text { (comp } \\
\text { arable } \\
\text { prices) }\end{array}$ & $\begin{array}{l}\text { Retail } \\
\text { trade } \\
\text { turno } \\
\text { ver of } \\
\text { non- } \\
\text { foodst } \\
\text { uffs in } \\
2020 \text {, } \\
\text { mln, }\end{array}$ & $\begin{array}{c}\text { Retail } \\
\text { trade } \\
\text { turnover } \\
\text { of non- } \\
\text { foodstuffs } \\
\text { (compara } \\
\text { ble } \\
\text { prices), in } \\
\text { the } \\
\text { Russian }\end{array}$ \\
\hline
\end{tabular}




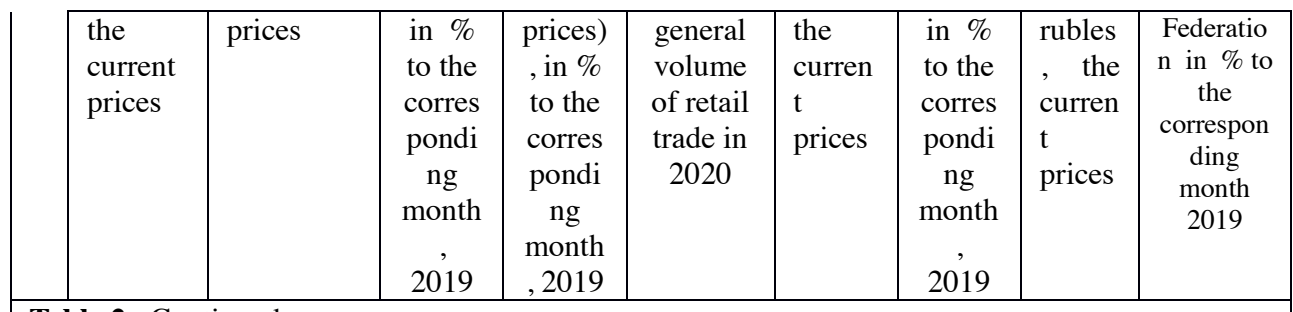

Table 2. Continued

\begin{tabular}{|c|c|c|c|c|c|c|c|c|c|}
\hline 1 & $\begin{array}{c}45 \\
883,60\end{array}$ & 47748,20 & 102,5 & 100,1 & $49 / 51$ & $\begin{array}{c}1276, \\
8\end{array}$ & 102,3 & 1363 & 103 \\
\hline 2 & $\begin{array}{c}44 \\
803,50\end{array}$ & 46648,70 & 103,4 & 103,4 & $49 / 51$ & $\begin{array}{c}1269, \\
7\end{array}$ & 103,8 & $\begin{array}{c}1359, \\
2\end{array}$ & 105,6 \\
\hline 3 & $\begin{array}{c}50 \\
328,90 \\
\end{array}$ & 52851,10 & 101,7 & 104,5 & $\begin{array}{c}48,8 / 51, \\
2 \\
\end{array}$ & 1413 & 104,8 & $\begin{array}{c}1504, \\
5\end{array}$ & 106,5 \\
\hline 4 & $\begin{array}{c}45 \\
139,60 \\
\end{array}$ & 37696,00 & 92,2 & 76,4 & $\begin{array}{c}54,5 / 45 \\
5 \\
\end{array}$ & $\begin{array}{c}1216, \\
3\end{array}$ & 90,8 & 893,7 & 63,6 \\
\hline 5 & $\begin{array}{c}45 \\
852,00\end{array}$ & 38049,90 & 91,9 & 75,7 & $\begin{array}{c}54,6 / 45 \\
4\end{array}$ & $\begin{array}{c}1251, \\
4\end{array}$ & 91,4 & $\begin{array}{c}1005, \\
9\end{array}$ & 70,8 \\
\hline 6 & $\begin{array}{c}45 \\
985,90 \\
\end{array}$ & 42270,90 & 92,6 & 82,4 & $\begin{array}{c}52,1 / 47 \\
9\end{array}$ & $\begin{array}{c}1321, \\
3\end{array}$ & 96,3 & $\begin{array}{c}1302, \\
2\end{array}$ & 88,7 \\
\hline 7 & $\begin{array}{c}48 \\
024,70\end{array}$ & 46104,00 & 95 & 87,1 & $51 / 49$ & н/д & н/д & $\mathrm{H} /$ д & $\mathrm{H} /$ д \\
\hline
\end{tabular}

Note: Compiled by authors according to materials: Office of the Federal State Statistics Service in the Sverdlovsk and Kurgan regions, https://rosstat.gov.ru/

to replenish stocks in time, thereby increasing sales.

The turnover of foodstuffs trade in the Sverdlovsk region and the Russian Federation has almost equal deviations in April-May 2020 from the corresponding period in 2019. The sale of non-foodstuffs showed the greatest sustainability in the Sverdlovsk region with the ban on offline trade of the most shopping centers and non-foodstuffs retail outlets (table 2).

The process of increasing the number of COVID-19 cases in Russia has changed the work conditions of online and offline trade. According to the real-time data of the Federal State Statistics Service, in June 2020 the online sales figures for large and medium-sized trade organizations in the Russian Federation decreased by $2,4 \%$ in comparison with May 2020 (in comparable prices). And they increased by 2.5 times in comparison with June 2019.

The share of online sales in the total retail turnover of these organizations was $5,7 \%$ in comparison with $2,4 \%$ in June 2019. The trends in the development of the local consumer market in the new conditions (the pandemic) are revealed. Such a form of e-commerce as a marketplace and Click\&Collect service is widely used. There is a growing demand for courier delivery services.

In the conditions of the COVID-19 turmoil the consumer market neutralize the destabilization and receive the incentive for the further sustainable development of the economy.

\section{Conclusion}


The main scientific conclusions obtained in the course of the research are the following.

In the conditions of the pandemic, it is extremely important to develop methods for managing the sustainable development of national and regional social and economic systems.

The sustainable functioning of the consumer market is a necessary condition for the transition of the region - the Sverdlovsk region- to the sustainable development model.

The economic and social factors are manageable. Improving the management model during the pandemic, they can manage the sustainability of the consumer market and the region.

The analysis of social and economic indicators in the Sverdlovsk region showed that the sustainable development is constrained by a number of factors. It is necessary to identify these factors and work to eliminate their destructive influence.

Innovative technologies have a significant influence on the sustainable development of the consumer market, especially during the pandemic. Investments and state support will ensure the sustainable development of the region.

To ensure the sustainable development of the region, it is necessary to use fully the potential of the consumer market, to strengthen the local production, local traditions and local self-government. All these measures will increase its importance in forming the sustainable development of the region.

\section{References}

1. P.A. Minakir, Spatial Economics. Economic Analysis of Dimension in Space, 1 (2014)

2. A. Dobson, Sustainable Development and the Defence of the Natural World (2000)

3. I. Moffatt, Sustainable Development: Principles, Analysis and Policies (1996)

4. D. Reid, Sustainable development: an introductory guide (1995)

5. V. K. Chertykovtsev, The problem of stability of development of socio-economic systems (2014)

6. A.G. Granberg, V.I.Suslov, S.A. Suspitsyn, Reg.: Economics and Social Sciences, Economic and Mathematical Studies of Multiregional Systems, 2, 120 (2008)

7. Our common future, Report of the International Commission on Environment and Development (ICED) (1983)

8. P. Marcuse, Sustainability is not enough. Environment and Urbanization (1998)

9. Strategy for spatial development of the Russian Federation for the period up to 2025 , Order of the Government of the Russian Federation No. 207-r dated February 13, 2019 (2019)

10. V. V. Klimanov, S. M. Kazakova, A. A. Mikhaylova. Econom., Retrospective analysis of the sustainability of Russian regions as socio-economic systems, 5, (2019)

11. N. V. Novikova, Munits: Economics and Management., Conceptual and terminological apparatus for the study of the local consumer market, 1 (2012) 